\title{
Perception and Practices of COVID-19 in Rural Areas of Southeastern Nigeria: A Community-based Cross-sectional Survey
}

\author{
Emmanuel I. Nnamonu ${ }^{a^{*}}$, Ogonna C. Ani $^{b}$, Love C. Okafor ${ }^{c}$, \\ Godwin C. Nwosu $^{d}$, Obiageli A. Okeke ${ }^{e}$, Pauline N. Ikwuegbu ${ }^{f}$, \\ Chukwudi P. Ota ${ }^{\text {a }}$, Chukwuemeka F. Egwim ${ }^{\text {a }}$, Chukwuemeka L. Agu ${ }^{\text {a }}$ \\ and Benjamin U. Ononye ${ }^{\mathrm{e}}$

\footnotetext{
${ }^{a}$ Federal College of Education, Eha-Amufu, School of Sciences, Department of Biology, Nigeria. ${ }^{b}$ Ebonyi State University, Abakaliki, Faculty of Biological Sciences, Department of Applied Biology, Nigeria.

${ }^{c}$ Alex Ekwueme Federal University Teaching Hospital, Department of Obstetrics and Gynaecology, Abakaliki Ebonyi State Nigeria. ${ }^{d}$ University of Nigeria, Nsukka, Faculty of Biological Sciences, Department of Zoology and Environmental Biology, Nigeria.

${ }^{e}$ Nnamdi Azikiwe University, Awka, Faculty of Biological Sciences, Department of Zoology, Nigeria. ${ }^{f}$ Federal College of Education, Eha-Amufu the Office of the Provost, Nigeria.
}

Authors' contributions

This work was carried out in collaboration among all authors. Authors EIN, OCA, LCO, GCN, OAO, provided all the materials used for this study. Author EIN designed this research. Authors EIN, OCA,

LCO, GCN, OAO, PNI, CPO, CLA and CFE were responsible for the field work, handled monitored

the process of data collection, statistical analysis and result interpretation. The manuscript was prepared by author EIN and edited by all authors. The final version was read and approved by all authors. All authors agree to be accountable for all aspects of this manuscript in ensuring that any questions related to the accuracy or integrity of any part of the work are appropriately investigated and resolved. All authors read and approved the final manuscript.

Article Information

DOI: $10.9734 / A R R B / 2022 / v 37 i 230484$

Open Peer Review History: This journal follows the Advanced Open Peer Review policy. Identity of the Reviewers, Editor(s) and additional Reviewers, peer review comments, different versions of the manuscript, comments of the editors, etc are available here: https://www.sdiarticle5.com/review-history/76537

Original Research Article

Received 20 October 2021 Accepted 12 November 2021 Published 10 February 2022 


\section{ABSTRACT}

Aims: Despite all efforts made globally by governments of various nations and all concerned agencies through preventative measures, quick testing, isolation, shutting down of societies and economy, the virus still succeeded in spreading through communities perhaps due to the wrong perspective, in addition to surveillance, prevention and management challenges. This study evaluated the perception and practices of covid-19 in rural areas of southeastern Nigeria.

Study Design: The study adopted a community-based cross-sectional survey design that investigated awareness, perspective, surveillance challenges, prevention, management and economic impact in rural settlement areas of south-east, Nigeria.

Place and duration of study: This study was be conducted in rural settlement areas of south-east Nigeria (Abia, Anambra, Ebonyi, Enugu, and Imo states). February - April, 2021.

Methodology: Data was collected by the use of the questionnaire. Five hundred copies were administered per state.

Results: Most participants (2464, 98.6\%) heard first of COVID-19 through radio/television (1409, $56.3 \%)$, social media $(539,21.5 \%)$ and their friends/relatives $(418,16.7 \%) ; 1896(75.8 \%)$ believed in the existence of COVID-19 infection. However, the majority in Ebonyi state (309, 61.8\%) had their disbelief on the existence of COVID-19. Participants confirmed having knowledge of COVID-19 testing $(2319,92.8 \%)$ and isolation centers $(2299,92.0 \%)$, however, a major challenge was lack of $(1698,67.9 \%)$ or no awareness $(550,22.0 \%)$ of masses testing centre in their areas. A few individuals $(392,15.7 \%)$ reported having experienced one or two COVID-19 symptoms about 3 months ago. Knowledge on how to prevent contracting COVID-19 is relatively high (66.7\%) among the respondents. COVID-19 induced economic burden amongst residents were mainly as a result of the imposition of lockdown to movements and businesses $(1098,43.9 \%)$, disruption of studies (959, $38.4 \%)$, increased hunger $(950,38.0 \%)$, high expenditure $(894,35.8 \%)$ and loss of job/income $(816$, $32.6 \%)$.

Conclusion: It is concluded that the majority of the people in southeast Nigeria are aware of the possible existence of Covid-19 in their area.

Keywords: COVID-19; Economic impact; Perception; Practices; Rural areas; South-East Nigeria.

\section{INTRODUCTION}

Coronavirus disease 2019 (COVID-19) pandemic has been declared a new disease, separate from other diseases caused by coronaviruses [severe acute respiratory syndrome (SARS) and Middle East Respiratory Syndrome (MERS)] [1] Currently, the total confirmed cases of Covid-19 have reached over $220,697,522$ with more than $4,567,506$ deaths and over 198,072,562 recoveries globally [2]. COVID-19 pandemic has directly and indirectly affected every individual, family, community, and society across the world. It has altered daily lives, recessed economies of nations, disrupted the chain of socioeconomic relations, exposed the poor health care systems in many nations, induced fears globally, and has exerted indefinable hardship globally because societies and economies were placed on hold in order to curtail the ability of the virus to spread through communities. Its impacts have led to severe and widespread increases in global food insecurity, affecting vulnerable households in almost every country, with impacts expected to continue through 2021, into 2022, and possibly beyond as the Delta variant continues its spread.

Researchers have documented reports on awareness, perception and the practice of COVID-19 prevention among residents of a state in the South-South region of Nigeria. Owhonda et al. [3] reported that the most common sources of information about COVID-19 were radio jingles and television adverts. Most respondents had poor knowledge of COVID-19. Some respondents believed they were unlikely to contract the virus. Only a few of the respondents washed all the critical parts of their hands correctly. Adebowale et al. [4] in a study on SARS-CoV-2 (COVID-19 pandemic) in Nigeria: Multi-institutional survey of knowledge, practices, and perception amongst undergraduate veterinary medical students reported that respondents' mean knowledge and practice scores were $22.7(\mathrm{SD} \pm 3.0)$ and $24.1(\mathrm{SD} \pm 2.9)$, respectively with overall $63.4 \%$ and $88.8 \%$ displaying good knowledge and satisfactory practice levels. However, relatively lower proportions showed adherence to avoiding 
touching face or nose (19.5\%), face maskwearing $(58.1 \%)$, and social distancing $(57.4 \%)$. Al-Hanawi et al. [5] on a study Knowledge, Attitude and Practice Toward COVID-19 Among the Public in the Kingdom of Saudi Arabia: A Cross-Sectional Study documented that majority of the study participants were knowledgeable about COVID-19, had indicating optimistic attitudes, showed good practices; men have less knowledge, less optimistic attitudes, and less good practice toward COVID-19 than women. They also found that older adults are likely to have better knowledge and practices, than younger people.

Despite all efforts made globally by governments of various nations and all concerned agencies through preventative measures, quick testing, isolation, shutting down of societies and economy, the virus still succeeded in spreading through communities perhaps due to the wrong perspective, in addition to surveillance, prevention, and management challenges.

Nations including Nigeria have reopening economy with caution and fear of possible resurging of the virus infection. Nigeria Centre for Disease Control (NCDC) recently reported a total of 195,511 confirmed cases of COVID-19 out of which there 8,430 active cases, 184,529 discharged cases, 2,552 deaths. So far, out of over 200, 000000 million population of Nigerians only $2,779,725$ samples have been tested [2]. In Nigeria, it appears some people are yet to accept that viral infection exists in the country. This disbelief could greatly stifle any control effort employed. It is necessary to ascertain the level of COVID-19 awareness of the general population to facilitate control efforts.

The present study was conducted in rural settlements of southeast region of Nigeria. The region is made up of five states Abia, Anambra, Ebonyi, Enugu and Imo. The residents of the rural areas are dominant of the Igbo-speaking tribe, mainly rural farmers, traders, fishermen, artisans, and civil servants. It was discovered that most interior villages/communities in our study area people live together and share things in common. Specifically, they farm, bath in the same stream, share densely populated market, prefer eating together from same plate, etc. as a way of life. Consequently, even with the coming of COVID-19, they find it difficult to adjust. Many of them do not believe that the disease is real. Health care facilities in many villages are in a bad state. Considering the current low physician/patient ratio of 1:2500 in Nigeria, an outburst of COVID-19 in rural settlements will expose the country's poor health care system and endanger many lives. laccarino [6] stated that the propensity for disease transmission is higher among the people that live in close proximity. Basically, higher population could spur challenges in sanitation and declined quality of living conditions and potentially serves as a breeding venue for infectious agents and rapid transmission.

This study was prompted by an observed high level of the wrong perception of COVID-19 amongst the inhabitants of our chosen study area, surveillance, prevention and management challenges. There is also a dearth of literature on perspective, surveillance challenges, prevention, management and economic impact of COVID-19 in rural settlement areas of south-east, Nigeria. The present study was designed to investigate the perspective, surveillance challenges, prevention, management and economic impact of COVID-19 in rural settlement areas of southeast, Nigeria.

\section{MATERIALS AND METHODS}

\subsection{Study Area}

This study was be conducted in rural settlement areas of southeast Nigeria (Abia, Anambra, Ebonyi, Enugu, and Imo states).

\subsection{Study Design, Population, and Informed Consent}

The study adopted a community-based crosssectional survey design that investigated awareness, perspective, surveillance challenges, prevention, management, and economic impact in rural settlement areas of south-east, Nigeria. All the needed data were obtained using a structured questionnaire, which was administered to the respondents across the states for a period of 3 months (February - April, 2021).

The study population was all adults in the five south-eastern states of Nigeria. The participants were recruited with the assistance of fellow academic staff colleagues from involved states (Abia, Anambra, Ebonyi, Enugu, and Imo states). The sample size for the study was calculated using Kasiulevicus et al. [7] formula, and a total of 2,500 participants from the five states were randomly sampled, after being briefed on the 
purpose of the study for informed consent, and their confidentiality were assured.

\subsection{Data Collection}

Data were collected with a questionnaire. Five hundred (500) copies of a structured questionnaire containing information on the socio-demographic characteristic of the respondents, community awareness and perspective on COVID-19, challenges to community surveillance on covid-19 and prevention, management, and impact of COVID19 were administered to respondents randomly from each of the five states that make up southeastern Nigeria.

\subsection{Statistical Analysis}

The data collected from the investigation were analyzed using Statistical Package for Social Sciences (SPSS) version 20.0 (IBM Corporation, Armonk, USA). Descriptive statistics of mean, frequencies, and percentages were used to compare the studied parameters in the various states. Results were presented in tables.

\section{RESULTS}

Table 1 shows the socio-demographic characteristics of respondents in the study area. The males were slightly greater in preponderance $(1419,56.8 \%)$ than the females $(1081,43.2 \%)$, as observed in all the states except for Ebonyi with higher female respondents $(254,50.8 \%)$ than males (246, $49.2 \%)$. The age mean value of the respondents is $31.99 \pm 9.76$, with the majority of them being 30 years old. Overall marital status of the respondents showed that single individuals (1206, 48.2\%) were higher among residents that gave consent to participate in the study, followed by the married $(1154,46.2 \%)$. This is however true for Ebonyi, Enugu, and Imo states, but not for Abia and Anambra states with higher consented participants among the married individuals (Table 1). A greater preponderant of the participants had tertiary and secondary level education with 1079 (43.1\%) and 999 (40.0\%) values respectively. A total of $814(32.6 \%)$ and $748(29.9 \%)$ of the participants are self-employed and salary-employed respectively. Others are mainly students $(590,23.6 \%)$ and farmers (306, $12.2 \%$ ) with very few jobless individuals (42, $1.7 \%$ ). Christianity is the religion of practice for most of the participants (2302, 92.1\%).
Participants from Abia and Anambra states recorded $100 \%$ practice of Christian religion, while Ebonyi had 84 (16.8\%) and $35(7.0 \%)$ of the respondents as Muslims and atheists respectively. Also, individuals that practice African traditional religion were observed in Ebonyi (51, 10.2\%), Enugu (15, 3.0\%) and Imo $(13,2.6 \%)$.

Table 2 shows the community awareness and perspective on COVID-19 among residents in the study area. It was observed that most of the participants $(2464,98.6 \%)$ heard of COVID-19 through radio/television (1409, 56.3\%), social media $(539,21.5 \%)$ and their friends/relatives $(418,16.7 \%)$. Apart from awareness through radio/television, participants in Abia and Anambra that reported they first heard of COVID19 through friends/relatives, were higher than those first heard through social media (Table 2). Health campaigns $(87,3.5 \%)$ and religious Centres like churches or mosques $(49,2.0 \%)$ were the least sources that the participants first heard of COVID-19. In all the states, overall, of $2181(87.2 \%)$ of the respondents attested being aware of the COVID-19 symptoms and believed that elderly people $(2184,87.4 \%)$ are most prone to its infection. On the existence of COVID-19 in Nigeria and the study area (South East), a greater preponderant of the participants (1897, $75.9 \%)$ and (1896, 75.8\%) respectively believed its existence. However, it was observed that in Ebonyi state, the majority of the participants had their disbelief on the existence of COVID-19 both in Nigeria and in their state $(309,61.8 \%)$.

Table 3 shows the challenges to community surveillance on COVID-19 among residents in the study area. The majority of the residents confirmed the presence of centers in their states for COVID-19 testing $(2319,92.8 \%)$ and isolation $(2299,92.0 \%)$ for individuals. Also, the preferred care-seeking option for COVID-19 is a hospitalbased intervention for most of the participants (1826, $73.0 \%)$. There were more or less few masses testing for COVID-19 in the study area as the majority of the respondents reported none (1698, 67.9\%), others don't know (550, 22.0\%), with just few individuals $(252,10.1 \%)$ that attested to testing programme in their states (Table 3). The residents' awareness of and contact to NCDC are high, as the majority of them have heard $(2197,87.9 \%)$ and have contact $(2135,85.4 \%)$ to NCDC. Further, many of the residents don't know nor believe that there are COVID-19 positive (53.0\%, 44.7\%) and death $(61.7 \%, 34.1 \%)$ cases in their states 
Table 1. Socio-demographic characteristics of respondents in South-East Nigeria

\begin{tabular}{|c|c|c|c|c|c|c|c|}
\hline \multirow[t]{2}{*}{ Parameter } & \multirow[t]{2}{*}{ Variables } & \multicolumn{5}{|l|}{ States } & \multirow[t]{2}{*}{ Total } \\
\hline & & Abia & Anambra & Ebonyi & Enugu & Imo & \\
\hline \multirow[t]{2}{*}{ Sex } & Male & $279(55.8)$ & $281(56.2)$ & $246(49.2)$ & $306(61.2)$ & 307 (61.4) & $1419(56.8)$ \\
\hline & Female & $221(44.2)$ & $219(43.8)$ & $254(50.8)$ & $194(38.8)$ & $193(38.6)$ & 1081 (43.2) \\
\hline \multirow[t]{2}{*}{ Age } & Mean \pm SD & $31.92 \pm 6.1$ & $32.20 \pm 7.98$ & $31.58 \pm 9.69$ & $32.11 \pm 12.52$ & $32.12 \pm 12.49$ & $31.99 \pm 9.76$ \\
\hline & Mode & 32 & 32 & 30 & 30 & 30 & 30 \\
\hline \multirow[t]{4}{*}{ Marital status } & Single & $144(28.8)$ & $164(32.8)$ & $298(59.6)$ & $301(60.2)$ & $299(59.8)$ & $1206(48.2)$ \\
\hline & Married & $300(60.0)$ & 291 (58.2) & 195 (39.0) & $184(36.8)$ & $184(36.8)$ & $1154(46.2)$ \\
\hline & Divorced & $35(7.0)$ & $28(5.6)$ & $0(0.0)$ & $0(0.0)$ & $0(0.0)$ & $63(2.5)$ \\
\hline & Widowed & $21(4.2)$ & $17(3.4)$ & $7(1.4)$ & $15(3.0)$ & $17(3.4)$ & $77(3.1)$ \\
\hline \multirow[t]{4}{*}{ Educational level } & None & $6(1.2)$ & $3(6.0)$ & $71(14.2)$ & $0(0.0)$ & $0(0.0)$ & $80(3.2)$ \\
\hline & Primary & $82(16.4)$ & $72(14.4)$ & $154(30.8)$ & $18(3.6)$ & $16(3.2)$ & $342(13.7)$ \\
\hline & Secondary & $288(57.6)$ & $297(59.4)$ & $95(19.0)$ & $156(31.2)$ & $163(32.6)$ & 999 (40.0) \\
\hline & Tertiary & $124(24.8)$ & $128(25.6)$ & $180(36.0)$ & $326(65.2)$ & $321(64.2)$ & $1079(43.1)$ \\
\hline \multirow[t]{5}{*}{ Occupation } & None & $0(0.0)$ & $0(0.0)$ & $10(2.0)$ & $16(3.2)$ & $16(3.2)$ & $42(1.7)$ \\
\hline & Salary-employed & $159(31.8)$ & $184(36.8)$ & $114(22.8)$ & $145(29.0)$ & $146(29.2)$ & 748 (29.9) \\
\hline & Self-employed & $182(36.4)$ & $170(34.0)$ & $198(39.6)$ & $135(27.0)$ & $129(25.6)$ & $814(32.6)$ \\
\hline & Farming & $89(17.8)$ & $78(15.6)$ & $77(15.4)$ & $30(6.0)$ & $32(6.4)$ & 306 (12.2) \\
\hline & Student & $70(14.0)$ & $68(13.6)$ & $101(20.2)$ & $174(34.8)$ & $177(35.4)$ & $590(23.6)$ \\
\hline \multirow[t]{4}{*}{ Religion } & None & $0(0.0)$ & $0(0.0)$ & $35(7.0)$ & $0(0.0)$ & $0(0.0)$ & $35(1.4)$ \\
\hline & Christianity & $500(100.0)$ & $500(100.0)$ & $330(66.0)$ & $485(97.0)$ & $487(97.4)$ & $2302(92.1)$ \\
\hline & Islam & $0(0.0)$ & $0(0.0)$ & $84(16.8)$ & $0(0.0)$ & $0(0.0)$ & $84(3.4)$ \\
\hline & Traditional & $0(0.0)$ & $0(0.0)$ & $51(10.2)$ & $15(3.0)$ & $13(2.6)$ & $79(3.1)$ \\
\hline
\end{tabular}

Values are expressed as the frequency with percentages in parenthesis, $n$ (\%), whereas age is expressed as Mean $\pm S D$ 
Table 2. Community awareness and perspective on COVID-19 among residents in South-East Nigeria

\begin{tabular}{|c|c|c|c|c|c|c|}
\hline \multirow[t]{2}{*}{ Variables } & \multicolumn{5}{|l|}{ States } & \multirow[t]{2}{*}{ Total } \\
\hline & Abia & Anambra & Ebonyi & Enugu & Imo & \\
\hline \multicolumn{7}{|l|}{ Heard of COVID-19? } \\
\hline Yes & $494(98.8)$ & $495(99.0)$ & $493(98.6)$ & $493(98.6)$ & $489(97.8)$ & $2464(98.6)$ \\
\hline No & $6(1.2)$ & $5(1.0)$ & $7(1.4)$ & $7(1.4)$ & $11(2.2)$ & $36(1.4)$ \\
\hline \multicolumn{7}{|l|}{ Source you first heard? } \\
\hline Radio/TV & $308(61.6)$ & $292(58.4)$ & $278(55.6)$ & $278(55.6)$ & $253(50.6)$ & $1409(56.3)$ \\
\hline Health campaigns & $18(3.6)$ & $20(4.0)$ & $15(3.0)$ & $15(3.0)$ & $19(3.8)$ & $87(3.5)$ \\
\hline Social media & $74(14.8)$ & $85(17.6)$ & $121(24.2)$ & $120(24.0)$ & $139(27.4)$ & $539(21.5)$ \\
\hline Church/mosque & $12(2.4)$ & $10(2.0)$ & $9(1.8)$ & $9(1.8)$ & $9(1.8)$ & $49(2.0)$ \\
\hline Friends/relatives & $88(17.6)$ & $93(18.6)$ & $77(15.4)$ & $78(15.6)$ & $82(16.4)$ & $418(16.7)$ \\
\hline \multicolumn{7}{|c|}{ Aware of COVID-19 symptoms? } \\
\hline Yes & $459(91.8)$ & $486(97.2)$ & $400(80.0)$ & $399(79.8)$ & $437(87.4)$ & $2181(87.2)$ \\
\hline No & $41(8.2)$ & $14(2.8)$ & $100(20.0)$ & $101(20.2)$ & $63(12.6)$ & $319(12.8)$ \\
\hline \multicolumn{7}{|c|}{ Are people most prone to COVID-19? } \\
\hline Children & $0(0.0)$ & $0(0.0)$ & $29(5.8)$ & $30(6.0)$ & $35(7.0)$ & $94(3.7)$ \\
\hline Adolescents & $72(14.4)$ & $66(13.2)$ & $31(6.2)$ & $28(5.6)$ & $25(5.0)$ & $222(8.9)$ \\
\hline Elderly people & $428(55.6)$ & $434(86.8)$ & $440(88.0)$ & $442(88.4)$ & $440(88.0)$ & $2184(87.4)$ \\
\hline \multicolumn{7}{|c|}{ Existence of covid-19 in Nigeria? } \\
\hline Yes & $420(84.0)$ & $449(89.8)$ & $191(38.2)$ & $419(83.8)$ & $418(83.6)$ & $1897(75.9)$ \\
\hline No & $80(16.0)$ & $51(10.2)$ & $309(61.8)$ & $81(16.2)$ & $82(16.4)$ & $603(24.1)$ \\
\hline \multicolumn{7}{|c|}{ Existence of covid-19 in your state? } \\
\hline Yes & $420(84.0)$ & $449(89.8)$ & $191(38.2)$ & $419(83.8)$ & $417(83.4)$ & $1896(75.8)$ \\
\hline No & $80(16.0)$ & $51(10.2)$ & $309(61.8)$ & $81(16.2)$ & $83(16.6)$ & $604(24.2)$ \\
\hline
\end{tabular}


Table 3. Challenges to community surveillance on COVID-19 among residents in South-East Nigeria

\begin{tabular}{|c|c|c|c|c|c|c|}
\hline \multirow[t]{2}{*}{ Variables } & \multicolumn{5}{|l|}{ States } & \multirow[t]{2}{*}{ Total } \\
\hline & Abia & Anambra & Ebonyi & Enugu & Imo & \\
\hline \multicolumn{7}{|c|}{ COVID-19 testing centre close-by? } \\
\hline Yes & $500(100.0)$ & $500(100.0)$ & $319(63.8)$ & $500(100.0)$ & $500(100.0)$ & $2319(92.8)$ \\
\hline No & $0(0.0)$ & $0(0.0)$ & $181(36.2)$ & $0(0.0)$ & $0(0.0)$ & $181(7.2)$ \\
\hline \multicolumn{7}{|c|}{ COVID-19 isolation centre close-by? } \\
\hline Yes & $488(97.6)$ & $489(97.8)$ & $344(68.8)$ & $489(97.8)$ & $489(97.8)$ & $2299(92.0)$ \\
\hline No & $12(2.4)$ & $11(2.2)$ & $156(31.2)$ & $11(2.2)$ & $11(2.2)$ & $201(8.0)$ \\
\hline \multicolumn{7}{|c|}{ Care-seeking preference for COVID? } \\
\hline Traditional & $99(19.8)$ & $97(19.4)$ & $190(38.0)$ & $155(31.0)$ & $108(21.6)$ & $649(26.0)$ \\
\hline Hospital & $395(79.0)$ & $402(80.4)$ & $298(59.6)$ & $345(69.0)$ & 386 (77.2) & $1826(73.0)$ \\
\hline Religion & $6(1.2)$ & $1(0.2)$ & $12(2.4)$ & $0(0.0)$ & $6(1.2)$ & $25(1.0)$ \\
\hline \multicolumn{7}{|c|}{ Mass testing for COVID in your area? } \\
\hline Yes & $81(16.2)$ & $140(28.0)$ & $29(5.8)$ & $0(0.0)$ & $2(0.4)$ & $252(10.1)$ \\
\hline No & 371 (74.2) & $357(71.4)$ & 466 (93.2) & $252(50.4)$ & $252(50.4)$ & $1698(67.9)$ \\
\hline Don't know & $48(9.6)$ & $3(0.6)$ & $5(1.0)$ & $248(49.6)$ & 246 (49.2) & $550(22.0)$ \\
\hline \multicolumn{7}{|l|}{ Heard of NCDC? } \\
\hline Yes & $480(96.0)$ & $477(95.4)$ & $282(56.4)$ & $481(96.2)$ & 477 (95.4) & 2197 (87.9) \\
\hline No & $20(4.0)$ & $23(4.6)$ & $218(43.6)$ & $19(3.8)$ & $23(4.6)$ & $303(12.1)$ \\
\hline \multicolumn{7}{|c|}{ Contacts/accessibility to NCDC? } \\
\hline Yes & $454(90.8)$ & $451(90.2)$ & $325(65.0)$ & $454(90.8)$ & $451(90.2)$ & $2135(85.4)$ \\
\hline No & $46(9.2)$ & $49(9.8)$ & $175(35.0)$ & $46(9.2)$ & $49(9.8)$ & $365(14.6)$ \\
\hline \multicolumn{7}{|c|}{ COVID-19 positive cases in your area? } \\
\hline Yes & $16(3.2)$ & $5(1.0)$ & $15(3.0)$ & $16(3.2)$ & $5(1.0)$ & $57(2.3)$ \\
\hline No & $187(37.4)$ & $179(35.8)$ & $386(77.2)$ & $187(37.4)$ & $180(36.0)$ & $1119(44.7)$ \\
\hline Don't know & $297(59.4)$ & $316(63.2)$ & $99(19.8)$ & $297(59.4)$ & $315(63.0)$ & $1324(53.0)$ \\
\hline \multicolumn{7}{|c|}{ CovID-19 death cases in your area? } \\
\hline Yes & $15(3.0)$ & $30(6.0)$ & $18(3.6)$ & $14(2.8)$ & $29(5.8)$ & $106(4.2)$ \\
\hline No & $95(19.0)$ & $139(27.8)$ & $383(76.6)$ & $95(19.0)$ & $140(28.0)$ & $852(34.1)$ \\
\hline Don't know & $390(78.0)$ & $331(66.2)$ & $99(19.8)$ & $391(78.2)$ & $331(66.2)$ & $1542(61.7)$ \\
\hline \multicolumn{7}{|c|}{ Any challenges to COVID-19 testing? } \\
\hline Yes & $494(98.8)$ & $497(99.4)$ & $415(93.0)$ & $494(98.8)$ & $497(99.4)$ & $2397(95.9)$ \\
\hline No & $6(1.2)$ & $3(0.6)$ & $35(7.0)$ & $6(1.2)$ & $3(0.6)$ & $53(2.1)$ \\
\hline \multicolumn{7}{|c|}{ Any COVID-19 associated stigma? } \\
\hline Yes & $486(97.2)$ & $478(95.6)$ & $325(65.0)$ & $486(97.2)$ & $478(95.6)$ & $2253(90.1)$ \\
\hline No & $14(2.8)$ & $22(4.4)$ & $175(35.0)$ & $14(2.8)$ & $22(4.4)$ & $247(9.9)$ \\
\hline
\end{tabular}


respectively (Table 3 ). Greater preponderant (2397, 95.9\%) of the participants envisaged possible challenges to COVID-19 community testing compliance and claimed that there exists palpable stigma associated with COVID-19 infection in their states $(2253,90.1 \%)$.

Table 4 shows the prevention practices of COVID-19 among residents in the study area. from the result, symptoms like high fever (1213, $48.5 \%)$, breathing difficulty $(1097,43.9 \%)$ and dry cough $(949,38.0 \%)$ were the most notable. Others include catarrh (670, 26.8\%) and weakness $(726,29.0 \%)$. Few individuals reported having experienced any of the COVID-19 symptoms about 3 months ago (392, 15.7\%). Knowledge on how to prevent contracting COVID-19 is relatively high among the respondents with an overall of 1667 (66.7\%) residents that claimed they have knowledge on COVID-19 prevention practices. Preventive measures like regular hand washing with soap (1807, 72.3\%), hand sanitizing (1030, 41.2\%), use of face mask $(817,32.7 \%)$, and sneezing into elbow $(720,28.8 \%)$, among others, are the most practiced measures among the residents (Table 4). It is noteworthy also that most of the respondents $(2135,85.4 \%)$ reported that they have not seen any COVID-19 patient before.

Table 5 shows the management strategies and impact of COVID-19 among residents in the study area. Knowledge of treatment for COVID19 is low among the residents (274, $11.0 \%)$. However, most of them reported that they are aware of some treatment options practiced elsewhere like taking of malaria drugs (809, $32.4 \%)$, going to the hospital $(753,30.1 \%)$, herbal concoctions $(406,16.2 \%)$, and food supplements $(343,13.7 \%)$, among others. The overall efforts of NCDC and other health workers were rated high by the majority of the residents (1267, 50.7\%), especially from Ebonyi, Enugu, and Imo states, whereas Abia and Anambra residents rated their efforts as mainly low and moderate (Table 5). The economic burden due to COVID-19 among the residents was mainly a result of the imposition of lockdown to movements and businesses (1098, 43.9\%). Others are disruption of studies (959, 38.4\%), increased hunger (950, 38.0\%), high expenditure $(894,35.8 \%)$ and loss of job/income (816, $32.6 \%)$. The majority of the residents across states $(1944,77.7 \%)$ complained of the high economic impact of COVID-19, with few individuals that rated the impact to be rather moderate $(424,17.0 \%)$ and low $(132,5.3 \%)$.

\section{DISCUSSIONS}

This study evaluated issues on Covid-19 disease awareness, perspective, surveillance challenges, prevention, management and economic impact in rural settlement areas of the southeast, Nigeria. Considering the fact that Nigeria is the largest and most densely populated country in Africa and the 7th largest population in the world, with approximately 200 million people on a landmass area of $920,000 \mathrm{~km}(360,000 \mathrm{sq} \mathrm{mi})$, having approximately more than $60 \%$ of its population as urban dwellers, and the urbanization rate is estimated at $4.3 \%$, over $60 \%$ are younger than 25 years and the aged population is only $3.3 \%$ [8]. It is obvious that a lesser portion of its population settles in the rural areas and a lesser proportion also fall within the very old ages which are more prone to the COVID-19 scourge. Ibrahim [9] reported that timely and accurate of surveillance data is an essential element for effective Covid-19 interventions. Surveillance is a cornerstone for controlling the Covid-19 pandemic. Enhancing Covid-19 surveillance is vital for rapid cases detection, containing spread \& ending pandemic.

The socio-demographic characteristics of respondents in this study showed an age mean value of the respondents is $31.99 \pm 9.76$ (with majority of them being 30 years old). A greater number of them are self-employed including farmers and students. These findings are consonants with CIA [8]. The population are majorly Christians with a little fraction of that practice African traditional religion. It will be important to also note that our researchers targeted a population that would be able to fill our instrument for data collection properly.

It was observed that most of the participants heard of COVID-19 through the media mainly radio/television. Most rural areas in our study area do not have access to a weak network, some do not have access at all. Consequently, most of them rely on radioltelevision as the mass media through which they receive information. On the other hand, only few of the respondents admitted that they first heard of COVID-19 through a health campaign. This reflects the level of negligence rural settlement arears suffer in Nigeria especially southeast Nigeria. Most times, health workers decline to work in the rural areas because some of the locations do not have access roads and most health facilities in rural areas are in a deteriorating state. Specifically, at the heat of COVID-19 in Nigeria, safety gadgets 
Table 4. Prevention practices of COVID-19 among residents in South-East Nigeria

\begin{tabular}{|c|c|c|c|c|c|c|}
\hline \multirow[t]{2}{*}{ Variables } & \multicolumn{5}{|l|}{ States } & \multirow[t]{2}{*}{ Total } \\
\hline & Abia & Anambra & Ebonyi & Enugu & Imo & \\
\hline \multicolumn{7}{|c|}{ COVID-19 infection symptoms? } \\
\hline High fever & $115(23.0)$ & $114(22.8)$ & $323(64.6)$ & $327(65.4)$ & $334(66.8)$ & $1213(48.5)$ \\
\hline Breathing difficulty & $128(25.5)$ & $139(27.8)$ & $217(43.4)$ & $303(60.6)$ & $310(62.0)$ & 1097 (43.9) \\
\hline Dry cough & $66(13.2)$ & $54(10.8)$ & $220(44.0)$ & $301(60.2)$ & $308(61.6)$ & $949(38.0)$ \\
\hline Catarrh & $102(20.4)$ & $99(19.8)$ & $114(22.8)$ & $176(35.2)$ & $179(35.8)$ & $670(26.8)$ \\
\hline Weakness & $81(16.2)$ & $72(14.4)$ & $153(30.6)$ & $205(41.0)$ & $215(43.0)$ & $726(29.0)$ \\
\hline All of the above & $207(41.3)$ & $203(40.6)$ & $149(29.8)$ & $223(44.6)$ & $218(43.6)$ & $1000(40.0)$ \\
\hline Don't know & $129(25.7)$ & $121(24.2)$ & $108(21.6)$ & $16(3.2)$ & $15(3.0)$ & $389(15.6)$ \\
\hline \multicolumn{7}{|c|}{ Experienced any above in last 3 months? } \\
\hline Yes & $48(9.6)$ & $26(5.2)$ & $70(14.0)$ & $40(8.0)$ & $208(41.6)$ & $392(15.7)$ \\
\hline No & $452(90.4)$ & $474(94.8)$ & $430(86.0)$ & $460(92.0)$ & $292(58.4)$ & $2108(84.3)$ \\
\hline \multicolumn{7}{|c|}{ Know how to prevent COVID-19? } \\
\hline Yes & $338(67.6)$ & $288(57.6)$ & $389(77.8)$ & $382(76.4)$ & $270(54.0)$ & $1667(66.7)$ \\
\hline No & $162(32.4)$ & $212(42.4)$ & $111(22.2)$ & $118(23.6)$ & $230(46.0)$ & $833(33.3)$ \\
\hline \multicolumn{7}{|c|}{ COVID preventive measures practiced? } \\
\hline Hand wash with soap & $484(96.6)$ & $486(97.2)$ & $280(56.0)$ & $275(55.0)$ & $282(56.4)$ & $1807(72.3)$ \\
\hline Hand sanitizing & $69(13.8)$ & $65(13.0)$ & $369(73.8)$ & $259(51.8)$ & $268(53.8)$ & $1030(41.2)$ \\
\hline Face mask use & $20(4.0)$ & $14(2.8)$ & $118(23.6)$ & $330(66.0)$ & $335(67.0)$ & $817(32.7)$ \\
\hline Sneezing into elbow & $68(13.6)$ & 66 (13.2) & $158(31.6)$ & $211(42.2)$ & $217(43.4)$ & $720(28.8)$ \\
\hline Social distancing & $45(9.0)$ & $41(8.2)$ & $143(28.6)$ & $241(48.2)$ & $247(49.4)$ & $717(28.7)$ \\
\hline Avoiding crowds & $60(12.0)$ & $57(11.4)$ & $107(21.4)$ & $238(47.6)$ & $248(49.6)$ & $710(28.4)$ \\
\hline Non-shake of hands & $55(11.0)$ & $49(9.8)$ & $39(7.8)$ & $152(30.4)$ & $162(32.4)$ & 457 (18.3) \\
\hline Taking supplements & $40(8.0)$ & $36(7.2)$ & $50(10.0)$ & $29(5.8)$ & $31(6.2)$ & $186(7.4)$ \\
\hline Avoiding the sick & $21(4.2)$ & $21(4.2)$ & $52(10.4)$ & $56(11.2)$ & $61(12.2)$ & $211(8.4)$ \\
\hline All of the above & $25(5.0)$ & $28(5.6)$ & $19(3.8)$ & $81(16.2)$ & $74(14.8)$ & $227(9.1)$ \\
\hline \multicolumn{7}{|c|}{ Seen COVID-19 patient before? } \\
\hline Yes & $41(8.2)$ & $48(9.6)$ & $24(4.8)$ & $24(4.8)$ & $228(45.6)$ & $365(14.6)$ \\
\hline No & $459(91.8)$ & $452(90.4)$ & $476(95.2)$ & $476(95.2)$ & $272(54.4)$ & $2135(85.4)$ \\
\hline
\end{tabular}


Table 5. Management strategies and impact of COVID-19 among residents in South-East Nigeria

\begin{tabular}{|c|c|c|c|c|c|c|}
\hline \multirow{2}{*}{ Variables } & \multicolumn{5}{|l|}{ States } & \multirow{2}{*}{ Total } \\
\hline & Abia & Anambra & Ebonyi & Enugu & Imo & \\
\hline \multicolumn{7}{|c|}{ Know the treatment of COVID-19? } \\
\hline Yes & $44(8.8)$ & $62(12.4)$ & $61(12.2)$ & $61(12.2)$ & $46(9.2)$ & $274(11.0)$ \\
\hline No & $456(91.2)$ & $438(87.6)$ & $439(87.8)$ & $439(87.8)$ & $454(90.8)$ & $2226(89.0)$ \\
\hline \multicolumn{7}{|c|}{ Treatment options aware of/practiced? } \\
\hline Herbal concoction & $34(6.8)$ & $30(6.0)$ & $261(52.2)$ & $42(8.4)$ & $39(7.8)$ & $406(16.2)$ \\
\hline Food supplements & $11(2.2)$ & $12(2.4)$ & $218(43.6)$ & $51(10.2)$ & $51(10.2)$ & $343(13.7)$ \\
\hline Tradition practitioner & $8(1.6)$ & $12(2.4)$ & $30(6.0)$ & $26(5.2)$ & $24(4.8)$ & $100(4.0)$ \\
\hline Local store drugs & $33(6.6)$ & $27(5.4)$ & $43(8.6)$ & $64(12.8)$ & $65(13.0)$ & $232(9.3)$ \\
\hline Going to hospital & $124(24.8)$ & $133(26.6)$ & $110(22.0)$ & $194(38.8)$ & $192(38.4)$ & $753(30.1)$ \\
\hline Hot fluids with spices & $67(13.4)$ & $77(15.4)$ & $31(6.2)$ & $38(7.6)$ & $37(7.4)$ & $250(10.0)$ \\
\hline Taking malaria drugs & $296(59.1)$ & $310(62.0)$ & $89(17.8)$ & $57(11.4)$ & $57(11.4)$ & $809(32.4)$ \\
\hline \multicolumn{7}{|c|}{ Rate efforts of NCDC/health workers? } \\
\hline Low & $280(56.0)$ & $280(56.0)$ & $5(1.0)$ & $5(1.0)$ & $21(4.2)$ & $591(23.6)$ \\
\hline Moderate & $197(39.4)$ & $203(40.6)$ & $87(17.4)$ & $88(17.6)$ & $67(13.4)$ & $642(25.7)$ \\
\hline High & $23(4.6)$ & $17(3.4)$ & $408(81.6)$ & $407(81.4)$ & $412(82.4)$ & $1267(50.7)$ \\
\hline \multicolumn{7}{|c|}{ How has COVID-19 been a burden? } \\
\hline Lockdown imposition & $101(20.2)$ & $92(18.4)$ & $300(60.0)$ & $303(60.6)$ & $302(60.4)$ & 1098 (43.9) \\
\hline Loss of job/income & $189(37.7)$ & $176(35.2)$ & $111(22.2)$ & $168(33.6)$ & $172(34.4)$ & $816(32.6)$ \\
\hline Increased hunger & $164(32.7)$ & $154(30.8)$ & $167(33.4)$ & $230(46.0)$ & $235(47.0)$ & $950(38.0)$ \\
\hline Disruption of studies & $168(33.5)$ & 166 (33.2) & $204(40.8)$ & 206 (41.2) & $215(43.0)$ & $959(38.4)$ \\
\hline High expenditure & $157(37.0)$ & $185(37.0)$ & $171(34.2)$ & $191(38.2)$ & $190(38.0)$ & $894(35.8)$ \\
\hline \multicolumn{7}{|c|}{ Rate the COVID-19 economic impact? } \\
\hline Low & $7(1.4)$ & $13(2.6)$ & $4(0.8)$ & $4(0.8)$ & $104(20.8)$ & $132(5.3)$ \\
\hline Moderate & $4(0.8)$ & $7(1.4)$ & $171(34.2)$ & $155(31.0)$ & $87(17.4)$ & $424(17.0)$ \\
\hline High & $489(97.8)$ & $480(96.0)$ & $325(65.0)$ & 341 (68.2) & $309(61.8)$ & $1944(77.7)$ \\
\hline
\end{tabular}


were not dispatched to health facilities in rural areas. These findings are consonants with Amoo et al., [10] Etukudoh et al., [11] and Obeta et al., [12]

The majority believed that elderly people are most prone to COVID-19 infection in our study area. They also believed in the possible existence of COVID-19 in Nigeria and southeast Nigeria. However, it was observed that in Ebonyi state, the majority of the participants had a wrong perspective because they expressed disbelief on the existence of COVID-19 both in Nigeria and in their state. Some of them stated that politicians are deceiving them by preaching about a disease that is not in existence.

Some respondents confirmed knowledge of COVID-19 testing centers in their states and isolation for COVID-19 patients. They also confirmed non-mass testing for COVID-19 in their areas. In line with the above finding, it is important that note that there is only one Federal government-established sponsored COVID-19 testing center in entire southeast Nigeria. Obeta et al. [12] reported that the laboratory sites according to geopolitical zones are South West: 7 laboratories (Lagos, Ibadan, Ogun and Osun); South-South: 1 laboratory (Edo); southeast: 1 laboratory (Ebonyi); North Central/ FCT: 3 laboratories (Abuja, Jos); North West: 5 laboratories (Sokoto, Kano and Kaduna); and North East: 1 laboratory (Maiduguri). Therefore, it is long overdue for the Nigerian government through NCDC to establish laboratories capable of handling COVID-19 and another disease testing in all states.

They confirmed having NCDC's contact sent to them through various service providers. Further, many of the residents don't know nor believe that there are COVID-19 positive patients and death cases in their states respectively. A greater preponderant of the participants envisaged possible challenges to COVID-19 community testing compliance, and claimed that there exists palpable stigma associated with COVID-19 infection in their states. These findings were in line with Amoo et al. [10] and Etukudoh et al. [1112].

Knowledge of treatment for COVID-19 was low among the residents. Some responded that they preferred a care-seeking option for COVID-19 is hospital-based intervention if need be while others prefer treating with herbs used for malaria treatment and fruits found within their area. This collaborates with Nkereuwem et al., (2020) who stated that the Presidential Task Force, the NCDC and NAFDAC in collaboration with CDC and WHO should look into the use of indigenous products that could help in the management of COVID-19. Such should include herbs e.g., "Dogon yaro", and Nigerian food like vegetables and fruits - lemon, bitter cola, ginger, garlic, etc. Bitterly, some of residents rightly shared with us that COVID-19 cannot survive in their body because they often take alcohol. By implication that the alcohol will always dry and kill the virus causing CIVID-19.

The respondents confessed that economic burden caused by COVID-19 within our study areas were mainly as a result of the imposition of lockdown to movements and businesses, disruption of studies, increased hunger, high expenditure and loss of job/income. Majority of the residents across states complained of high economic impact of COVID-19. The lockdown was unavoidable because SARS-COV-2 has shown quick and easier transmission among the clusters, for example: family clusters, board room clusters, restaurant clusters etc. which has accounted for $50-80 \%$ of all confirmed cases of COVID-19 (Special Expert Group for Control of the Epidemic of Novel Coronavirus Pneumonia of the Chinese Preventive Medicine Association, [13-14].

\section{CONCLUSION}

The present study revealed that most participants have heard and also believe that COVID-19 exists in southeast Nigeria. Participants confirmed that there is a major challenge regards to lack or no awareness of the masses testing center in their areas. Knowledge on how to prevent contracting COVID-19 is relatively high among the respondents. COVID19 induced economic burden amongst residents were mainly as a result of the imposition of lockdown to movements and businesses, disruption of studies, increased hunger, high expenditure, and loss of job/income.

\section{DISCLAIMER}

The products used for this research are commonly and predominantly use products in our area of research and country. There is absolutely no conflict of interest between the authors and producers of the products because we do not intend to use these products as an avenue for any litigation but for the advancement of 
knowledge. Also, the research was not funded by the producing company rather it was funded by personal efforts of the authors.

\section{CONSENT}

As per international standard or university standard, Participants' written consent has been collected and preserved by the authors.

\section{ACKNOWLEDGEMENTS}

Authors appreciate all community union executives, village heads, church authorities, market union leaders, farmers, and others that assisted and volunteered to participate in this study.

\section{COMPETING INTERESTS}

Authors have declared that no competing interests exist.

\section{REFERENCES}

1. World Health Organisation. Coronavirus disease (COVID-19) pandemic; 2020.

2. Nigeria Centre for Disease Control. COVID-19 Case Updates- $2^{\text {nd }}$ September; 2021.

3. Owhonda G, Maduka O, Nwadiuto I, Tobin-West C, Azi E, Ojimah C, Alasia D, Olofinuka AM, Agala V, Paul JN, Nria D, Okafor C, Ndekwu I, Opara C, Newsom C. Awareness, perception and the practice of COVID-19 prevention among residents of a state in the South-South region of Nigeria: implications for public health control efforts. International Health. 2021; $0: 1-10$.

Available:https://doi.org/10.1093/inthealth/i hab046.

4. Adebowale OO, Adenubi OT, Adesokan HK, Oloye AA, Bankole NO, Fadipe OE, Ayo-Ajayi PO, Akinloye AK. SARS-CoV-2 (COVID-19 pandemic) in Nigeria: Multiinstitutional survey of knowledge, practices and perception amongst undergraduate veterinary medical students. PLoS ONE. 2021;16(3):e0248189.

Available:https://doi.org/10.1371/journal.po ne.0248189

5. Al-Hanawi MK, Angawi K, Alshareef $\mathrm{N}$, Qattan AMN, Helmy HZ, Abudawood Y, Alqurashi M, Kattan WM, Kadasah NA, Chirwa GC, Alsharqi O. Knowledge,
Attitude and Practice Toward COVID-19 Among the Public in the Kingdom of Saudi Arabia: A Cross-Sectional Study. Frontiers in Public Health. 2020;8(217).

DOI: $10.3389 /$ fpubh.2020.00217.

6. laccarino M. "Water, population growth and contagious diseases,". Water; 2019; 11(2): 386. View at: Publisher Site / Google Scholar Johns Hopkins Coronavirus Resource Center. COVID-19 Case Updates October; 2020.

7. Kasiulevicus V, Sapoka V, Filipaviciute R. Sample size calculation in epidemiological studies. Gerontologija. 2006;7(4):225-231.

8. Central Intelligence Agency (CIA), 9e World Fact Book. Age Structure, Central Intelligence Agency, McLean, VI, USA; 2020,

Available:https://www.cia.gov/library/public ations/the-worldfactbook/ields/341.html.

9. Ibrahim NK. Epidemiologic surveillance for controlling Covid-19 pandemic: types, challenges and implications. Journal of Infection and Public Health. Journal of Infection and Public Health; 2020; (In Press): 1-9.

10. Amoo EO, Adekeye O, Olawole-Isaac A, Fasina F, Adekola PO, Samuel GW, Akanbi MA, Oladosun M, Dominic E, Azuh DE. Nigeria and Italy Divergences in Coronavirus Experience: Impact of Population Density. The Scienti World J. 2020; Volume 2020 |Article ID 8923036 | Available:https://doi.org/10.1155/2020/892 3036.

11. Etukudoh NS, Ejinaka RO, Olowu FA, Obeta MU, Adebowale OM, Udoudoh MP. Coronavirus (COVID-19): Review from A Nigerian Perspective. Am J Biomed Sci \& Res. 2020;9(1):26-34.

12. Obeta MU, Ejinaka RO, Ofor IB. Nigeria is the Next Destination of COVID-19 (Coronavirus) Patients across the Globe, But the Strategic Plan for Medical Laboratories is in the Pipeline. Am J Biomed sci \& Res. 2020;8(4):324-325.

13. Special Expert Group for Control of the Epidemic of Novel Coronavirus Pneumonia of the Chinese Preventive Medicine Association. [An update on the epidemiological characteristics of novel coronavirus pneumoniaCOVID-19]. Zhonghua Liu Xing Bing Xue Za Zhi. 2020; 41:139-144.

14. National Population Commission. 2006 population and housing census priority table volume III: Population distribution by 
sex, State, Local Government Area and Senatorial District (Electronic version).

Abuja, Nigeria: National Population Commission; 2010.

(c) 2022 Nnamonu et al.; This is an Open Access article distributed under the terms of the Creative Commons Attribution License (http://creativecommons.org/licenses/by/4.0), which permits unrestricted use, distribution, and reproduction in any medium, provided the original work is properly cited.

Peer-review history:

The peer review history for this paper can be accessed here:

https://www.sdiarticle5.com/review-history/76537 